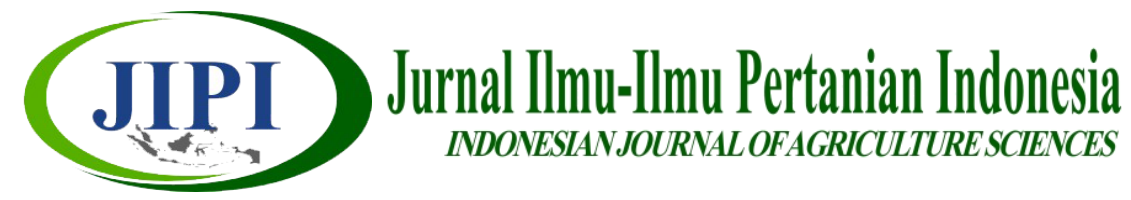

\title{
DETEKSI VIRUS TUNGRO PADA PADI DI BENGKULU
}

\author{
Mimi Sutrawati $^{1 *}$, Yenny $\operatorname{Sariasih}^{1}$, Priyatiningsih $^{1},{\text { Fausiah T. } \text { Ladja }^{2}}^{2}$ \\ ${ }^{1}$ Jurusan Perlindungan Tanaman, Fakultas Pertanian Universitas Bengkulu \\ ${ }^{2}$ Loka Penelitian Penyakit Tungro, Pusat Penelitian dan Pengembangan Tanaman Pangan \\ *Corresponding Author : mimi_sutrawati@unib.ac.id
}

\begin{abstract}
[DETECTION OF TUNGRO VIRUS ON RICE IN BENGKULU]. Several types of viruses have been reported to infect rice plants in Indonesia, including tungro, dwarf grass, and empty dwarfs. The spread of tungro in Indonesia in the beginning was only limited to certain regions in South Sulawesi, South Kalimantan, West Nusa Tenggara and North Sulawesi, but later it expanded to East Java, Central Java and Yogyakarta._In this study a tungro disease survey was conducted in several areas in Bengkulu Province. Virus detection is done by Loop-medated isothermal amplification (LAMP). Observations in the field showed that there were typical symptoms of tungro infection in rice plants, namely orange leaves starting from leaves to 2 and 3, little tillers, stunted plant growth. The results of detection with LampPCR showed rice samples from the district Pondok Kelapa Kab Bengkulu Tengah is positively infected with tungro virus.
\end{abstract}

Keyword: survey, symptom, virus detection

\begin{abstract}
ABSTRAK
Beberapa jenis virus telah dilaporkan menginfeksi tanaman padi di Indonesia antara lain penyebab tungro, kerdil rumput, dan kerdil hampa. Penyebaran tungro di Indonesia mula-mula hanya terbatas di beberapa daerah tertentu di Sulawesi Selatan, Kalimantan Selatan, Nusa Tenggara Barat dan Sulawesi Utara, kemudian meluas ke Jawa Timur, Jawa Tengah dan Yogyakarta. Namun hingga saat ini belum ada pembaharuan data sebaran penyakit tungro di Bengkulu. Maka dalam penelitian ini dilakukan survey lapang dengan metode purposive sampling. Survei dilakukan di beberapa daerah di Propinsi Bengkulu. Metode deteksi virus dilakukan dengan deteksi cepat menggunakan loop-mediated isothermal amplification LAMP. Pengamatan di lapangan menunjukkan adanya gejala khas infeksi tungro pada tanaman padi yaitu daun bergejala oranye mulai daun ke 2 dan ke 3, anakan sedikit, dan pertumbuhan tanaman terhambat. Hasil deteksi dengan Lamp-PCR menunjukkan sampel padi dari Kec. Pondok Kelapa Kab Bengkulu Tengah positif terinfeksi tungro.
\end{abstract}

Kata kunci: deteksi virus, gejala, lamp-pcr, survei 


\section{PENDAHULUAN}

Salah satu kendala dalam budidaya padi adalah serangan hama dan infeksi patogen. Di Indonesia, infeksi virus antara lain penyakit tungro menempati urutan ke lima dari hama dan penyakit penting pada padi setelah wereng coklat, penggerek batang, tikus dan blast. Produktivitas padi menjadi tidak optimal bahkan dapat mengalami puso gagal panen jika infeksi virus terjadi pada fase awal pertumbuhan padi atau fase vegetatif di pesemaian. Potensi kehilangan hasil akibat infeksi virus bervariasi bergantung pada umur tanaman saat terinfeksi, lokasi dan titik infeksi, musim tanam dan varietas padi. Semakin muda tanaman terinfeksi, maka semakin besar persentase kehilangan hasil yang ditimbulkan.

Beberapa jenis virus telah dilaporkan menginfeksi tanaman padi di Indonesia antara lain penyebab tungro, kerdil rumput, dan kerdil hampa. Penyakit tungro menempati urutan ke lima dari hama dan penyakit penting pada padi di indonesia setelah wereng coklat, penggerek batang, tikus dan blas. Pertama kali serangan tungro pada padi menyerang 25.000 ha sawah di Indonesia pada tahun 1983-1984 (Azzam \& Chancellor 2002). Penyebaran tungro di Indonesia mula-mula hanya terbatas di beberapa daerah tertentu di Sulawesi Selatan, Kalimantan Selatan, Nusa Tenggara Barat dan Sulawesi Utara, namun kemudian meluas ke Jawa Timur, Jawa Tengah dan Yogyakarta. Insiden penyakit tungro pernah dilaporkan di Bengkulu pada tahun 1990, dan belum ada laporan resmi status tungro di Bengkulu hingga saat ini. Namun, petani melaporkan adanya gejala serangan tungro di beberapa daerah di Bengkulu. Penelitian bertujuan untuk mengamati sebaran tungro di Bengkulu.

\section{METODE PENELITIAN}

Penelitian dilaksanakan September hingga Desember 2018. Survey dan pengambilan sampel dilakukan di persawahan di beberapa lokasi di Kota Bengkulu, Kab. Rejang Lebong, Propinsi Bengkulu, dan Kac. Belitang Kab. Ogan Komering Ulu Timur (OKU Timur), Propinsi Sumatera Selatan. Deteksi virus dengan metode Lamp-PCR yang dikembangkan oleh Balai Penelitian Jeruk dan Strawberi di Malang Jawa Timur dan Loka Penelitian Tungro di Sidrap, Sulawesi Selatan.

Pengamatan dan pengambilan sampel tanaman padi bergejala serta pengamatan serangga vektor dilakukan pada lahan persawahan di kota Bengkulu dan Kab. Bengkulu Selatan. Survei dilakukan pada saat tanaman berumur 3 hingga 5 minggu setelah tanam. Tanaman yang menunjukkan gejala terinfeksi tungro diambil sebagai sampel daun. Jumlah daun yang diambil sebagai sampel adalah tiga daun yang bergejala khas dari tiap rumpun padi yang bergejala. Sampel daun dimasukkan ke dalam kantung plastik dan disimpan dalam kotak untuk dibawa ke laboratorium. Beberapa rumpun tanaman bergejala juga di bawa ke laboratorium untuk dipelihara sebagai sumber inokulum tungro. Deteksi virus menggunakan metode Lamp-PCR dilakukan di Loka Penelitian Tungro di Sulawesi Selatan.

\section{HASIL DAN PEMBAHASAN}

Pengamatan di lapangan dilakukan pada saat tanaman berumur 3-5 minggu setelah tanam (mst). Tanaman padi menunjukkan gejala berupa perubahan warna daun menjadi oranye mulai daun ke 2 dan ke 3 , jumlah anakan sedikit, pertumbuhan tanaman terhambat (Gambar 1). Gejala tersebut merupakan gejala khas penyakit tungro. Gejala penyakit tungro ditemukan di semua lokasi survei di 3 kabupaten dan kota di Propinsi Bengkulu yaitu kota Bengkulu, Kab. Bengkulu Tengah, Kab, Bengkulu Selatan, Kab. Rejang Lebong, dan Kab. Ogan Komering Ulu Timur (Sumatera Selatan).

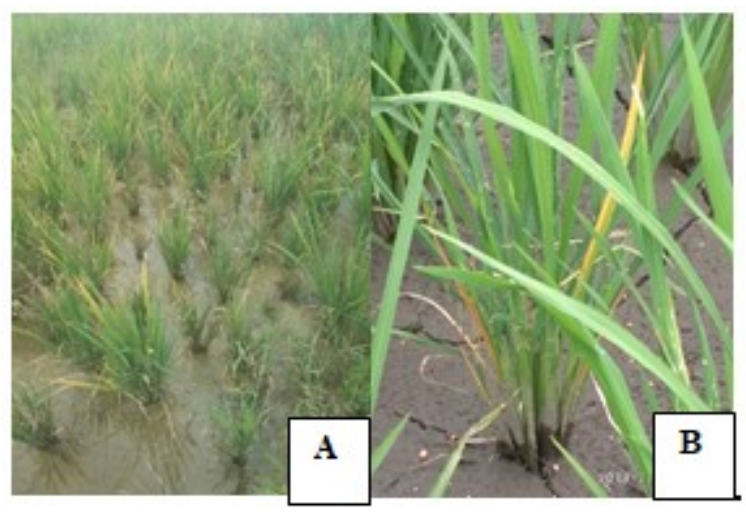

Gambar 1. Daun padi berwarna kuning oranye dan kerdil (A), daun ke 3 berwarna oranye (B)

Gejala utama penyakit tungro tampak pada perubahan warna pada daun muda menjadi kuning oranye dimulai dari ujung daun, daun muda menggulung, jumlah anakan berkurang, tanaman kerdil dan pertumbuhannya terhambat. Bila serangan berat terdapat bintik-bintik hitam pada daun. Gejala penyakit tersebar mengelompok, hamparan tanaman padi terlihat seperti bergelombang karena adanya perbedaan tinggi tanaman antara tanaman sehat dan yang terinfeksi. Intensitas serangan bergantung pada tingkat ketahanan varietas padi dan umur tanaman pada saat terinfeksi. Tanaman muda lebih peka terhadap infeksi dibanding tanaman tua. Gejala pertama pada umumnya timbul 6-15 hari setelah terinfeksi. Jika tanaman dapat terhindar dari infeksi sampai umur dua bulan, maka selanjutnya penyakit tungro kurang mengakibatkan kerusakan dan kehilangan hasil. Sedangkan derajat perubahan warna daun sangat bergantung pada varietas padi yang diserang dan faktor lingkungan. 
Deteksi virus tungro dengan metode Lamp-PCR menunjukkan hasil positif jika terjadi perubahan warna sampel dari ungu menjadi biru. Pengujian pada semua sampel menunjukkan bahwa sampel 4 dari Pondok Kelapa (Kab Bengkulu Tengah) positif terinfeksi tungro (Gambar 2). Hal ini membuktikan bahwa infeksi virus tungro terjadi pada padi sawah di Bengkulu. Beberapa sampel lainnya menunjukkan hasil negatif meski gejala infeksi tungro sangat khas dan jelas. Hasil pengujian sangat ditentukan oleh kualitas sampel uji. Hasil uji negatif pada sampel yang menunjukkan gejala khas terinfeksi tungro diduga berkaitan dengan rendahnya kualitas sampel tanaman.

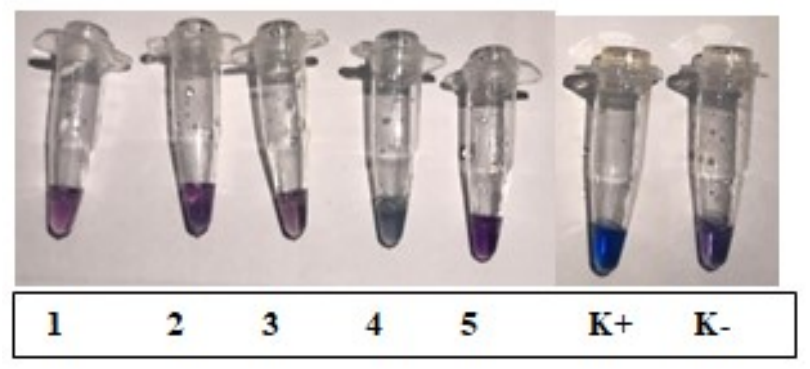

Gambar 2. Hasil deteksi virus tungro dengan Lamp-PCR, sampel 1=KS (kel. Semarang), sampel 2= RM (kel Rawa Makmur), sampel 3= BS (Bengkulu Selatan), sampel 4= PK (Pondok Kelapa), $\mathrm{K}+=$ kontrol positif, $\mathrm{K}$ - = kontrol negatif.

Metode loop-mediated isothermal amplification (LAMP) merupakan terobosan baru dalam deteksi berbasis asam nukleat (Notomi et al., 2000). Metode ini bekerja dengan menggunakan dua pasang primer yang mengenali 6 region dan mengamplifikasinya secara spesifik dalam keadaan isothermal pada sikuen target, tanpa harus menggunakan thermocycler. Metode Lamp telah digunakan untuk mendeteksi beberapa jenis virus yaitu Japanese yam mosaic virus (Fukuta et al., 2003), tomato spotted wilt virus (Fukuta et al., 2004), plum pox virus (Varga \& James, 2006) dan peach latent mosaic viroid (Boubourakas et al., 2009). Namun, metode ini belum banyak digunakan untuk deteksi virus pada padi. Metode ini lebih cepat dari pada deteksi virus dengan metode polymerase chain reaction (PCR).

Penyakit tungro disebabkan oleh dua jenis virus yang berbeda yaitu virus bentuk batang Rice tungro bacilliform virus (RTBV) dan virus bentuk bulat Rice tungro spherical virus (RTSV) (Agrios 2012). Kedua jenis virus tersebut tidak memiliki kekerabatan serologi dan dapat menginfeksi satu sel tanaman secara bersama-sama tanpa mengakibatkan proteksi silang antara keduanya.

Petani padi di Bengkulu menanam berbagai varietas padi (Tabel 1). Berdasarkan komunikasi pribadi dengan petani padi (2019), penyakit tungro yang biasa disebut petani sebagai penyakit merah pernah menyebabkan gagal panen.
Tabel 1. Lokasi survey penyakit tungro di Bengkulu dan hasil deteksi virus tungro dengan metode Lamp

\begin{tabular}{|c|c|c|c|c|}
\hline No. & Lokasi & Varietas & $\begin{array}{c}\text { Umur } \\
\text { tanaman } \\
\text { (mst) }\end{array}$ & $\begin{array}{c}\text { Hasil } \\
\text { deteksi } \\
\text { virus }\end{array}$ \\
\hline 1. & $\begin{array}{l}\text { Kel. Rawa Makmur } \\
\text { Kec.Muara } \\
\text { Bangkahulv Kota } \\
\text { Bengkulu }\end{array}$ & IR64 & 4 & - \\
\hline 2. & \begin{tabular}{|l|} 
Kel. Pondok Kelapa \\
Kab. Bengkulv \\
Tengah \\
\end{tabular} & Surya & 5 & + \\
\hline 3. & BPTP Bengkulv & Cigeulis & 3 & - \\
\hline 4. & $\begin{array}{l}\text { Seginim, Kab. } \\
\text { Bengkulv Selatan }\end{array}$ & IR merah & 4 & - \\
\hline 5. & \begin{tabular}{|l|} 
Kel. Padang Nangka \\
Kec. Singaran Pati, \\
Kota Bengkulv \\
\end{tabular} & IR 64 & 4 & - \\
\hline 6. & $\begin{array}{l}\text { Kelurahan Talang } \\
\text { Benih, Kec. Curup } \\
\text { Selatan, Kab. Rejang } \\
\text { Lebong }\end{array}$ & lokal & 5 & - \\
\hline 7. & $\begin{array}{l}\text { Desa Kejalo, Kec. } \\
\text { Curup Kab Rejang } \\
\text { Lebong }\end{array}$ & lokal & 8 & - \\
\hline 8. & $\begin{array}{l}\text { Kec. Belitang, Kab. } \\
\text { Okv Timus }\end{array}$ & lokal & 5 & $\cdots$ \\
\hline
\end{tabular}

Jika ada beberapa tanaman yang bergejala tungro pada awal musim tanam, maka penyakit akan menyebar dan menyebabkan gagal panen jika infeksi terjadi pada umur vegetatif. Penyebaran penyakit tungro sangat dipengaruhi oleh populasi serangga vektornya. Namun dalam penelitian ini belum ditemukan adanya serangga vektor di lapangan. Sebelumnya di Bengkulu pemah dilaporkan adanya tungro pada tahun 1990an dan belum ada status sebaran tungro hingga saat ini. Penelitian ini merupakan pendahuluan untuk mengkonfirmasi bahwa tungro masih menjadi masalah pada padi di Bengkulu. Namun dalam penelitian lokasi survei masih sangat terbatas sehingga perlu dilakukan survei lebih luas untuk mendapatkan data sebaran tungro yang lebih lengkap.

Pada tanaman padi, RTSV menyebabkan gejala kerdil yang ringan dan meningkatkan keparahan gejala yang disebabkan RTBV yaitu daun menguning dan kerdil (Hibino et. al 1978). N. virescens yang makan pada tanaman padi yang terinfeksi kedua jenis virus ini dapat menularkan RTBV dan RTSV secara bersamaan ataupun secara terpisah (Hibino et. al 1978; Hibino et.al. 1979). Wereng hijau dapat menularkan RTSV dari tanaman padi yang hanya terinfeksi RTSV dan RTBV, tetapi tidak mampu memindahkan RTBV dari tanaman yang hanya terinfeksi RTBV. Terdapat lima spesies wereng hijau yang dapat menularkan virus tungro yaitu Nephotettix virescens, N. nigropictus, N. malayamus, N. parvus dan Recilia dorsalis, Nilaparvata lugens. Wereng hijau menularkan virus tungro dengan efisiensi yang berbeda-beda dan $N$. virescens merupakan vektor terpenting karena efisiensi penularannya paling tinggi. Kedua partikel virus tersebut tidak bersirkulasi dalam 
tubuh vektor. Selain itu, virus tidak dapat ditularkan dari imago ke telur maupun antar perubahan stadia perkembangan. Serangga yang telah mendapatkan virus segera dapat menularkannya sampai virus yang diperoleh habis, sehingga kehilangan kemampuan menularkan virus. Masa terpanjang vektor mampu menularkan virus adalah 6 hari. Lama waktu yang dibutuhkan serangga untuk memperoleh virus antara 5-30 menit, sedangkan waktu yang dibutuhkan untuk menularkan virus juga singkat antara 7-30 menit. Periode inkubasi virus dalam tanaman antara 6-15 hari .

Pengendalian penyakit tungro dapat dilakukan dengan mengendalikan populasi serangga vektornya dan penggunaan varietas padi tahan wereng dan atau tahan tungro. Penanaman varietas tahan virus tungro dan wereng hijau merupakan komponen yang paling efektif dalam pengendalian tungro (Sama 1985, Loebenstein \& Gera 1993, Daradjat et al. 1999).

\section{KESIMPULAN}

Gejala penyakit tungro ditemukan di semua lokasi survei di 3 kabupaten dan kota di propinsi Bengkulu yaitu kota Bengkulu, Kab. Bengkulu Tengah, Kab, Bengkulu Selatan, Kab. Rejang Lebong, dan Kab. Ogan Komering Ulu Timur (Sumatera Selatan). Deteksi virus dengan metode Lamp-PCR menunjukkan bahwa sampel dari Pondok Kelapa (Kab Bengkulu Tengah) positif terinfeksi tungro. Perlu dilakukan survei lebih luas untuk mendapatkan luas serangan tungro di Bengkulu, serta deteksi jenis virus lainnya pada tanaman padi di Bengkulu .

\section{DAFTAR PUSTAKA}

Agrios, G.N. (2012). Plant Pathology. Academic Press., San Diego.

Azzam, O., Chancellor, T.C.B. (2002). The biology, epidemiology, and management of rice tungro disease in Asia. Plant Disease, 86(2), 88-100.

Boubourakas, I.N., Fukuta, S., Kyriakopoulou, P.E. (2009). Sensitive and rapid detection of peach latent mosaic viroid by the reverse transcription loop-mediated isothermal amplification. J. Virol. Methods 160, 63-68. DOI: https://doi.org/ 10.1016/j.jviromet.2009.04.021
Burhanuddin, Widiarta, I.N., Hassanuddin, A. (2006). Penyempurnaan pengendalian terpadu penyakit tungro dengan strategi menghindari infeksi dan pergiliran varietas tahan. JHPT Tropika, 6(2), 92-99. DOI: $h t t p: / / d x$.doi.org/10.23960/j.hptt.2692-99.

Daradjat, A. A., Widiarta, I.N. \& Hasanuddin, A. (1999). Breeding for rice tungro virus resistance in Indonesia. In T. C. B. Chancellor, O. Azzam, Kong Luen Heong (Ed). Rice Tungro Disease Management (pp. 3138). IRRI, Philippines.

Fukuta, S., Iida, T., Mizukami, Y., Ishida, A., Ueda, J., Kanbe, M., Ishimoto, Y. (2003). Detection of Japanese yam mosaic virus by RT-LAMP. Arch. Virol, 148,1713-1720. DOI: https://doi.org/10.1007/ s00705-003-0134-5

Fukuta, S., Ohishi, K., Yoshida, K., Mizukami, Y., Ishida, A., Kanbe, M. (2004). Development of immunocapture reverse transcription loop-mediated isothermal amplification for the detection of tomato spotted wilt virus from chrysanthemum. J. Virol. Methods, 121, 49-55. DOI: https://doi.org/10.1016/ j.jviromet.2004.05.016.

Hibino, H., Roechan, M., Sudarisman, S.(1978). Association of two types of virus particles with penyakit habang (tungro disease) of rice in Indonesia. Phytopathology, 68,1412-1416. DOI: https://doi.org/10.1094/ Phyto-68-1412

Hibino, H. Saleh, N., Roechan, M. (1979). Transmission of two kinds of rice tungro-associated viruses by insect vectors. Phytopathology, 69,1266-1268.

Loebenstein, G. \& Gera, A. (1993). The local lesion response to viruses possibilities for engineering resistant plants. Biotechnology in plant disease control. Wiley-liss, Inc. p.105-113.

Notomi, T., Okayama, H., Masubuchi, H., Yonekawa, T., Watanabe, K., Amino, N., Hase,T., (2000). Loop-mediated isothermal amplification of DNA. Nucl. Acids Res. 28, e63.

Sama, S. (1985). Penerapan konsep pergiliran varietas dalam pengelolaan penyakit tungro.Makalah Temu Lapang Pengendalian Penyakit Tungro. Banyumas, 18-19 September 1985.

Varga, A., James, D., (2006). Use of reverse transcription loop-mediated isothermal amplification for the detection of Plum pox virus. J. Virol. Methods, 138, 184-190. DOI: https://doi.org/10.1016/ j.jviromet.2006.08.014. 